\title{
Synthesis Characterization and Stereostructures of the Pyridazino[6,1-b]Quinazolinones
}

\author{
Abdullah G.M. Al-Sehemi \\ Department of Chemistry, Teacher's College \\ Abha, Saudi Arabia
}

\begin{abstract}
The title compounds pyridazino[6,1-b]quinazolinones were prepared in five steps from succinic anhydride in good yield without the need for chromatography. The barrier to rotation around the $N-N$ bond and concurrent ring-inversion in 7 and 15, was so low at room temperature by comparison with 3-diacylaminoquinazolinone. The preferred geometries have been determined by a Hartree-Fock and Density Function Theory calculation $\left[\mathrm{RHF} / 6-31 \mathrm{G}^{* *}(\mathrm{~d}), \mathrm{B} 3 \mathrm{LYP} / 6\right.$ $\left.311 \mathrm{G}^{* *}(\mathrm{~d})\right]$.
\end{abstract}

\section{Introduction}

Certain compounds containing quinazolinone ring system are known to possess a large variety of biological effects, particularly in the areas of antiinflammatory $^{[1]}$, anticonvulsive ${ }^{[2]}$, antibacterial ${ }^{[3]}$, antitumor ${ }^{[4]}$ and antihypertensive ${ }^{[5]}$.

The barrier to rotation about the $N-N$ bond is not sufficient to allow for separation of stereoisomers in monoacylaminoquinazolinones such as 1 unless the exocyclic nitrogen is additionally substituted. We have shown previously that 3diacylaminoquinazolin-4(3H)-ones, when the two acyl groups on the exocyclic nitrogen are different, the $N-N$ bond is a chiral axis with the two planes containing the quinazolinone and imide moieties orthogonal to one another ${ }^{[6-10]}$. The barrier to $N-N$ bond rotation is sufficiently high to allow separation of diastereoisomers (atropisomers) as in $2^{[11]}$. The activation barrier to rotation arises from an unfavourable eclipsing interaction during the transition state, involving the field $\mathrm{p}$-orbitals in each of the $\mathrm{sp}^{2}$-hybridised nitrogens and also due to strict interaction between the $N$-substituent (Scheme 1) ${ }^{[12]}$. 
<smiles>CC(C)C[SiH3]O[C@@H](c1nc2ccccc2c(=O)n1NC(=O)c1ccccc1)C(C)C</smiles>

1<smiles>CC(=O)N(C(=O)c1ccccc1)n1c([C@@H]([13CH2]C(C)(C)C)C(C)C)nc2ccccc2c1=O</smiles>

2

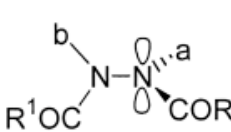<smiles></smiles><smiles>[R]OC(=O)[N+]([O])([O-])N([2H])C</smiles>

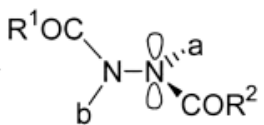

\section{Scheme 1}

\section{Results and Discussion}

Compounds 7 and 15 were of interest due to their structural similarity to the diacylaminoquinazoline such as 2 . In these compounds, however, incorporation of one of the acyl groups into the dihydropyridazinone ring holds it in an endo position and quinazolinone and imide planes cannot be orthogonal.

Pyridazinone 7 was prepared from succinic anhydride by the route shown in Scheme 2 in good yield $(72 \%)$ without need for chromatographic separation at any stage.
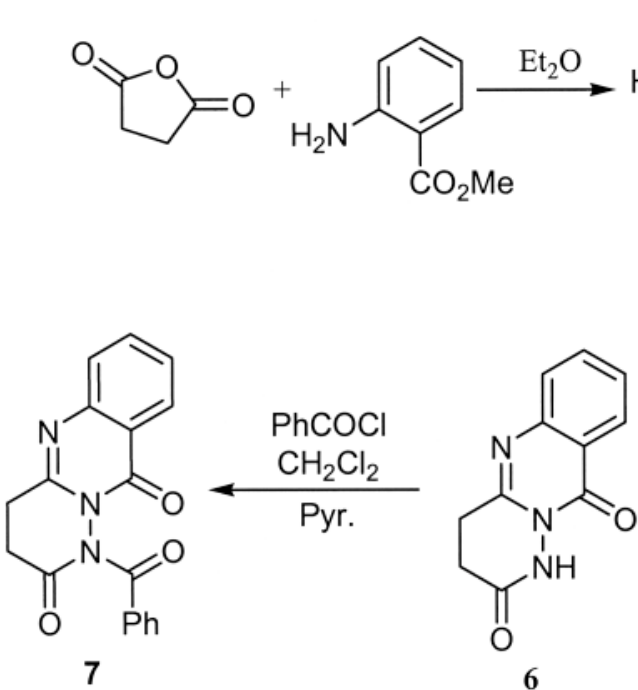<smiles>O=C1CCc2nc3ccccc3c(=O)n2N1</smiles><smiles>COC(=O)CCc1nc2ccccc2c(=O)n1N</smiles>

Scheme 2 
The proton NMR spectrum of 3 was of particular interest since the two methylene groups of the side-chain appeared equivalent, giving a sharp $4 \mathrm{H}$-singlet at 2.79. The two environments of these methylene groups were, however, sufficiently different to allow their identification in the ${ }^{13} \mathrm{C}-\mathrm{NMR}$ spectrum where there is a $3.4 \mathrm{ppm}$ difference in chemical shift.

Cyclisation of the anthranilate 3 to give their respective 3-aminoquinazolinones 4 was achieved efficiently by heating the former in ethanol under reflux and in the presence of an excess of hydrazine monohydrate. On cooling, the hydrazine salt was collected in quantitative yield. Dissolution in water followed by neutralization using glacial acetic acid gave the free acid-containing 3aminoquinazolinones in good yields and as crystalline white solids, without the need for subsequent purification. If, in the neutralization step the solution was made too acidic, the yields were observed to decrease suggesting that protonation of the quinazolinone ring occurred so reforming a water-soluble species. The mechanism for cyclisation is thought to involve initial attack of hydrazine on the more electrophilic ester carbonyl carbon to give an anthranil hydrazide 8 which intramolecularily attacks the amide carbonyl carbon. Subsequent dehydration affords the 3-aminoquinazolinone as its hydrazine salt (Scheme 3).

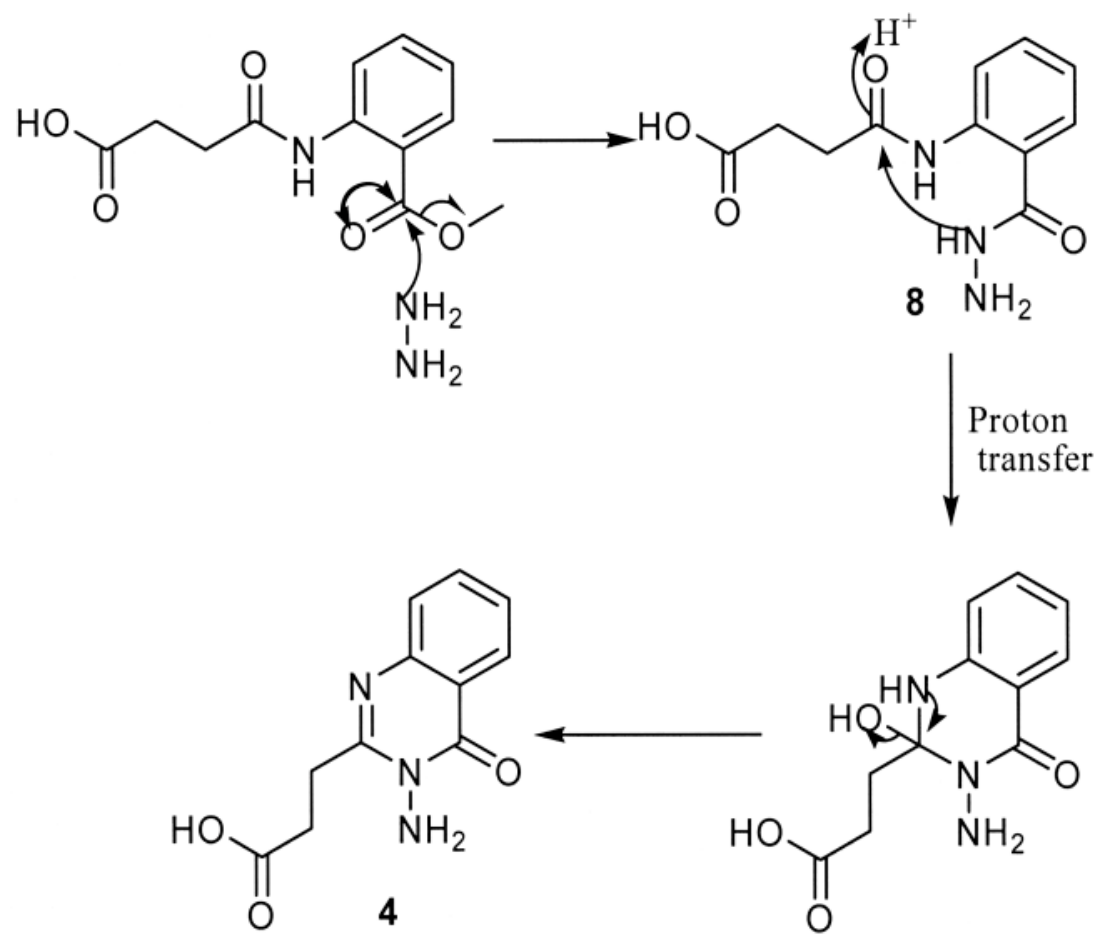

Scheme 3 


\section{Methyl Substituted Pyridazinone}

Racemic methyl succinic anhydride would provide the starting material for introduction of the methyl group into the side chain. Unlike succinic anhydride, methyl succinic anhydride is non-symmetrical so attack of a nucleophile on the two in equivalent carbonyl carbons results in two regioisomeric products. Direct synthesis of the required isomeric pyridazinone 10 and 11 is possible via nucleophilic attack of the anthranil hydrazide 9 in refluxing dry xylene as illustrated in (Scheme 4).

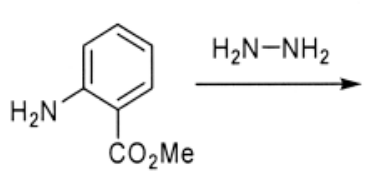

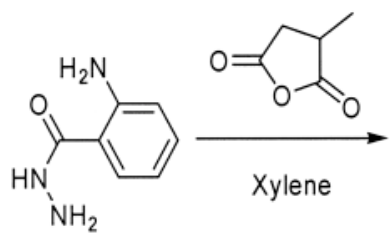

9

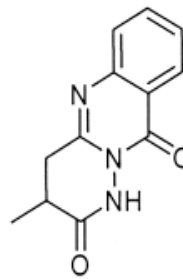

10

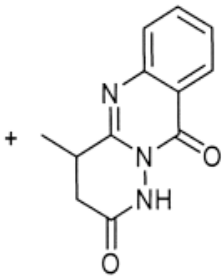

11

Scheme 4

However, this synthesis would require the subsequent separation of regioisomers 10 and 11 which was expected to be difficult. Consequently, the longer but reliable method that was used to prepare pyridazinone 6 was employed.

Reaction of methyl anthranilate with racemic methyl succinic anhydride gave methyl-N-(3-carboxymethylpropanoyl)anthranilate 12 and 13 (Scheme 5), easily distinguishable by NMR spectroscopy by comparison of the two distinct methyl signal doublets at 1.30 and $1.38 \mathrm{ppm}$ respectively (the sense of regselectivity will be discussed later). The major regioisomer 12 (33\%) was separated by crystallisation.

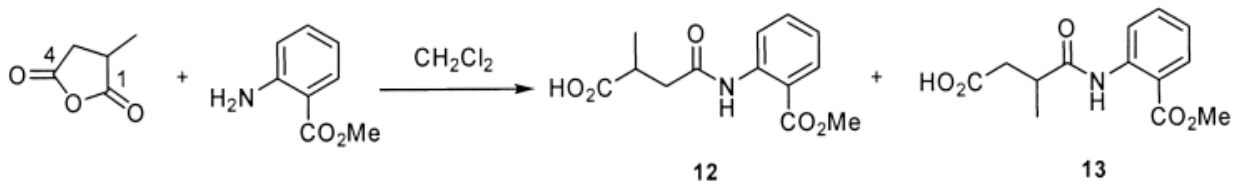

Scheme 5

The 3-aminoquinazolinone 14 was also synthesized via direct reaction of 12 with slightly excess amount of hydrazine monohydrate (Scheme 6).

\section{Regioselectivity in the Anthranil Ester Formation}

From the proton NMR spectra of the crude reaction product in (Scheme 5) the overall ratio of 12 to 13 was calculated at $8: 1$. Evidence that 12 and hence 


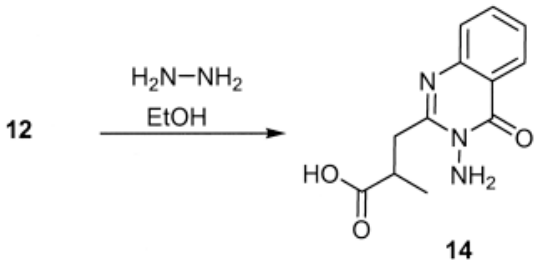

Scheme 6

quinazolinone 14, was the major regioisomer which formed from attack of methyl anthranilate on methyl succinic anhydride was obtained from several sources. Tentatively, relative chemical shift changes of the side-chain groups on converting 13 to 11 indicated 12 as being the major product. Additionally, nucleophilic attack by methyl anthranilate would be expected to occur at the less hindered carbonyl of methyl succinic anhydride, i.e., $\mathrm{C}(4)$ to give 12 (Scheme 5). Such observations though have only been shown to manifest themselves when small nucleophiles such as the hydride ions are employed. More conclusive evidence came from 2D-NMR and mass spectrometry experiments, carried out on the pure 3-aminoquinazolinone regioisomer 14 that had been isolated, as follows:

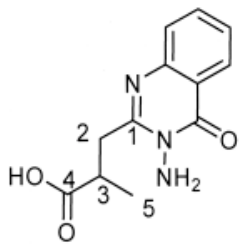

14

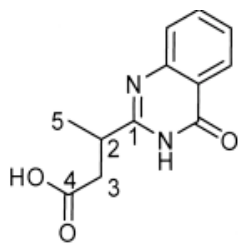

Interpretation of the recorded Heteronuclear Multiple Bond Correlation (HMBC) spectrum is based upon the assignments of $\mathrm{C}(1)$ and $\mathrm{C}(4)$, which are believed to be correct. The relative magnitudes of cross-peaks between these quaternary carbons and the protons of the side-chain are in agreement with 3aminoquinazolinone 14 as being the regioisomer present, as described below.

There are large cross-peaks at $\delta 3.0$ and $3.4 \mathrm{ppm}$ arising from a 2-bond coupling between $\mathrm{C}(1)$ and the two diastereotopic $\mathrm{C}(2) \mathrm{H}_{2}$ protons. Similarly, there are weak cross-peaks at $\delta 1.2$ and 3.1 due 4-bond [to $\mathrm{C}(5) \mathrm{H}_{3}$ ] and 3-bond [to $\mathrm{C}(3) \mathrm{H}$ ] couplings respectively, involving $\mathrm{C}(1)$. For $\mathrm{C}(4)$ the situation is reversed: it shows strong 2-bond and 3-bond cross-peaks at 3.1 and $1.2 \mathrm{ppm}$ to $\mathrm{C}$ (3) $\mathrm{H}$ and $\mathrm{C}(5) \mathrm{H}_{3}$, respectively. The cross peak with $\mathrm{C}(2) \mathrm{H}_{2}$ (3-bond) is weaker comparison to the case of $\mathrm{C}(1)$. 
With regard to mass spectroscopy, specific breakage of the $\mathrm{C}(2)-\mathrm{C}(3)$ bond would release fragments of differing molecular mass. By use of electron ionization such a cleavage was accomplished, resulting in an intense signal at $\mathrm{m} / \mathrm{z} 175$ corresponding to loss of the fragment $\mathrm{CH}\left(\mathrm{CH}_{3}\right) \mathrm{CO}_{2}^{-}$as can occur in 14. The lack of a peak at $\mathrm{m} / z 189$ resulting from loss of $\mathrm{CH}_{2} \mathrm{CO}_{2}^{-}$in the alternative regioisomer, provided mass spectral evidence that 14 was the preferentially formed regioisomer.

Geometry optimization by ab initio quantum mechanical calculations were carried out on the two possible regioisomers 12 and 13, using the GAUSSIAN $98 \mathrm{~W}$ package ${ }^{[12]}$. The geometries were optimized in vacuum on the levels of both Hartree-Fock (HF/6-31G) and Density Functional Theory (DFT/B3LYP/6$31 \mathrm{G}){ }^{[13]}$ To obtain improved energy comparisons second-order (MP2) and fourth-order Moller-Pleset perturbation (MP4) calculations were also carried out on the HF optimized geometries. The results of quantum mechanical calculations show that Methyl-N-(3-carboxy-2-methylpropanoyl)anthranilate (12) is the global energy minimum structure (Table 1$)$.

Table 1. The relative energies of two regioisomers from the various quantum mechanical methods.

\begin{tabular}{|c|c|c|c|c|}
\hline & \multicolumn{4}{|c|}{$\Delta \mathbf{E}(\mathrm{kca} / \mathrm{mol})$} \\
\hline Compounds & HF & MP2 & MP4 & DFT \\
\hline 12 & 0.0 & 0.0 & 0.0 & 0.0 \\
\hline 13 & 9.7 & 19.0 & 21.2 & 12.5 \\
\hline
\end{tabular}

The total energies for global minimum structure of 12 are HF $=-929.4483259$ hartree, MP2 $=-931.2981677$ hartree, MP4 $=-929.448341222$ hartree and DFT $=-935.0676402$ hartree. The MP2 and MP4 energies are obtained using the HF optimized structures.

\section{Cyclisation 14 to Provide its Pyridazinone Compound 10}

Conversion of 14 to pyridazinone 10 following the method described in (Scheme 2) would have involved initial formation of the methyl ester followed by pyrolysis to induce the intramolecular cyclisation. In an attempt to bring about a more direct synthesis ${ }^{[14]}$, was heated in acetic anhydride. Not surprisingly, the isolated product was the $\mathrm{N}$-acetyl pyridazinone 15 , formed by acetylation of nitrogen either before or after cyclisation to give the pyridazinone had occurred (Scheme 7). 


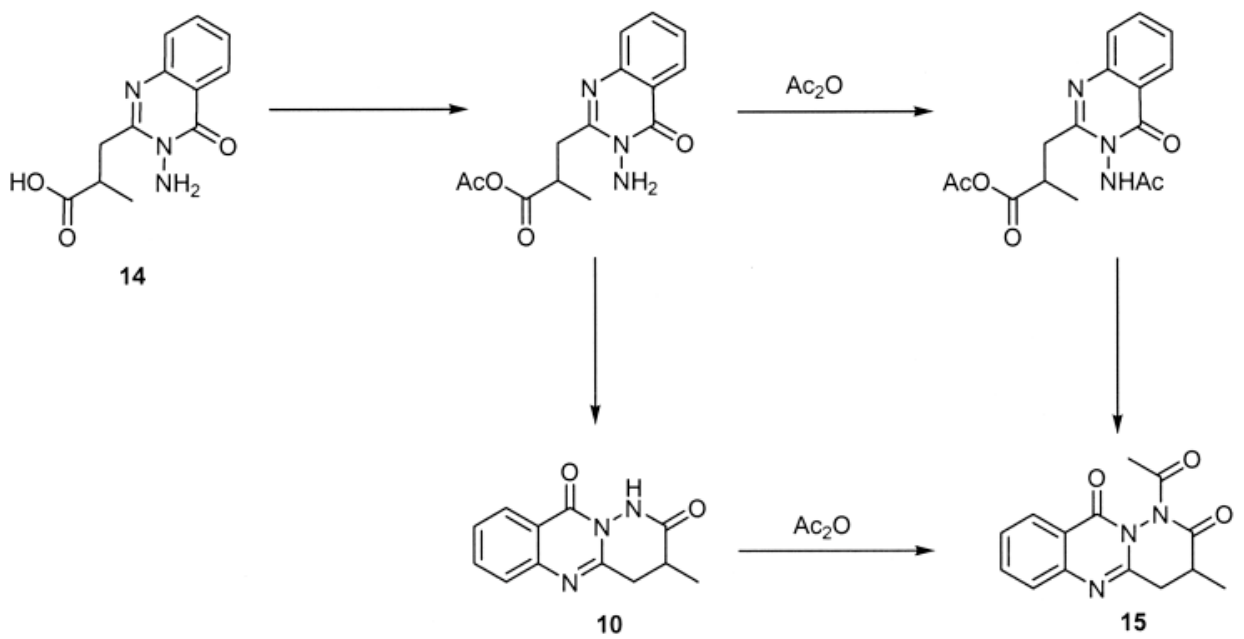

Scheme 7

\section{Stereostructures of Pyridazinonequnazolinone 7 and 15}

The synthesis of the parent pyridazinone compound 6 , formation of the new six-membered ring is favorable, however, the two filled p-orbitals from the adjacent $\mathrm{sp}^{2}$-hybridized nitrogens in the ring are orientated in a near eclipsing fashion $c f$. the preferred orthogonal arrangement found in DAQS ${ }^{[6-11]}$. This unfavourable interaction could provide an inherent stereoelectronic barrier to ringformation. The small angle between these p-orbitals in 7 and 15, is expected to raise the energy of the ground state conformation thereby making $\mathrm{N}-\mathrm{N}$ bond rotation comparatively easy to achieve, at least in comparison to DAQs. In the presumed transition state between the two rotamers (diastereoisomers) 15 and $15^{\prime}$ not only are the two p-orbitals directly eclipsing but the pyridazinone ring system becomes planar (Scheme 8). The two species inter converting via this transition state are diastereoisomeric, having different configurations for their $N-N$ Chiral axis. The nature of the transition state suggests that $N-N$ bond rotation and ring-inversion occur concurrently so providing a torsional as well as stereoelectronic barrier to interconversion.

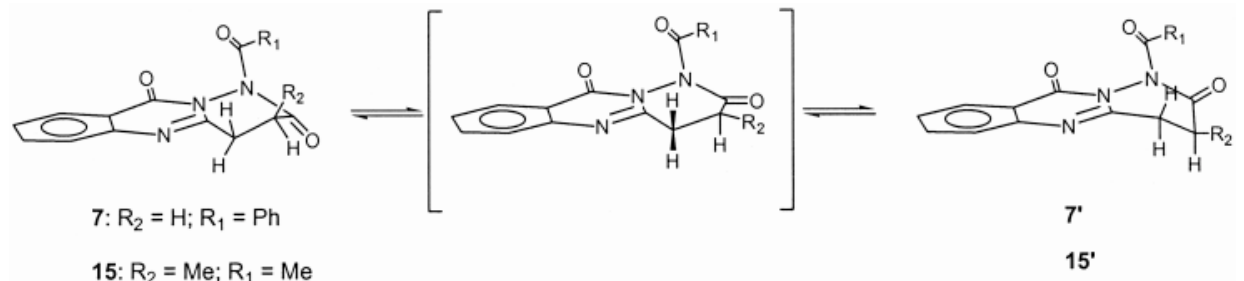

Scheme 8 
Consequently, a high-energy ground state may be compensated to some degree by a high-energy transition state leading to a high activation barrier for interconversion, albeit less than that believed to be present in DAQs. If the activation energy for interconversion in (Scheme 8) were large enough, then the $\mathrm{N}$ $N$ bond wound constitute a chiral axis, making identification and/or isolation of the two diastereoisomers possible. The barrier to $\mathrm{N}-\mathrm{N}$ bond rotation is considerably augmented in 3-diacylaminoquinazolinones by comparison with 3-monacylaminoquinazolinones. Consequently, a higher barrier to $N-N$ bond rotation is anticipated in $\mathrm{N}$-acylated pyridazinone 7 and 15 than their parent compound 6.

The proton NMR spectrum of N-acetylpyridazinone 15 was present as only one doublet signal for the methyl group. This seemed to disprove the initial suggestion that $\mathrm{N}-\mathrm{N}$ bond rotation would be sufficiently retarded on the NMR timescale to allow identification of the two diastereoisomers, where the methyl group is in an axial or equatorial position. The presence of a single methyl doublet signal can be explained if the energy difference between the two diastereoisomers is large enough such that only one (the preferred) diastereoisomer was observable on the NMR timescale. It was, however, noticed that all quinazolinone ring system. This broadening suggested an alternative explanation for the single methyl doublet the existence of two diastereoisomers that were rapidly interconverting on the NMR timescale due to a low barrier to $N-N$ bond rotation and concurrent ring-inversion. Lowering the temperature would be expected to retard the rate of interconversion making it possible to observe the two diastereoisomers. Decreasing the temperature to $0^{\circ} \mathrm{C}$ resulted in the methyl doublet broadening to a broad singlet. Simultaneously, the complex resonances due to the three ring protons also broadened and began to coalesce at $-20^{\circ} \mathrm{C}$. By the time the temperature had reached $-40^{\circ} \mathrm{C}$ the methyl resonances had reformed a well-defined doublet and the ring protons had begun to sharpen to a complex multiplet. It was anticipated that complete resolution of the latter signal could have been achieved by decreasing the temperature further, to the point where ring-inversion ceases to occur. Although the barrier to interconversion of the two species indicated (presumably the two diastereoisomers shown in (Scheme 8) has not been quantified it is clearly an order of magnitude less than that present in DAQs where analogous diastereoisomers can be separated and do not interconvert at room temperature. Again, the presence of only one methyl signal doublet at a temperature of $-40^{\circ} \mathrm{C}$ was unexpected. This suggested that the two doublets, resulting from the methyl group being in the axial or equatorial position had coincidentally at the same chemical shift. It is likely that the two methyl signals would have been more non-equivalent in a ${ }^{13} \mathrm{C}$ NMR spectrum also recorded at $-40^{\circ} \mathrm{C}$, though unfortunately this was also not performed. From this work it appears that the barrier for $N-N$ bond rotation in pyridazinones is much lower than for DAQs to the extent that a temperature of 
$-40^{\circ} \mathrm{C}$ is required to slow the process sufficiently for it to become visible on the NMR timescale.

In order to find whether a possible correlation could be established between the stereochemical endo (endo $\equiv \mathrm{C}=\mathrm{O}$ trans to quinazolinone group) and exo (exo $\equiv \mathrm{C}=\mathrm{O}$ cis to quinazolinone group) preference of two rotamers $7 \mathrm{a}$ and $7 \mathrm{~b}$ determined experimentally (NMR) and their relative stabilities, the estimation of the total energies for the model compound 7 was carried out, using several basis sets to evaluate basis set effects using the GAUSSIAN98 program ${ }^{[13]}$. For all calculations the most stable rotamers correspond to the endo structure $7 \mathrm{~b}$. The computational endo and exo configurations are illustrated in Fig. 1 along with their relative energies.

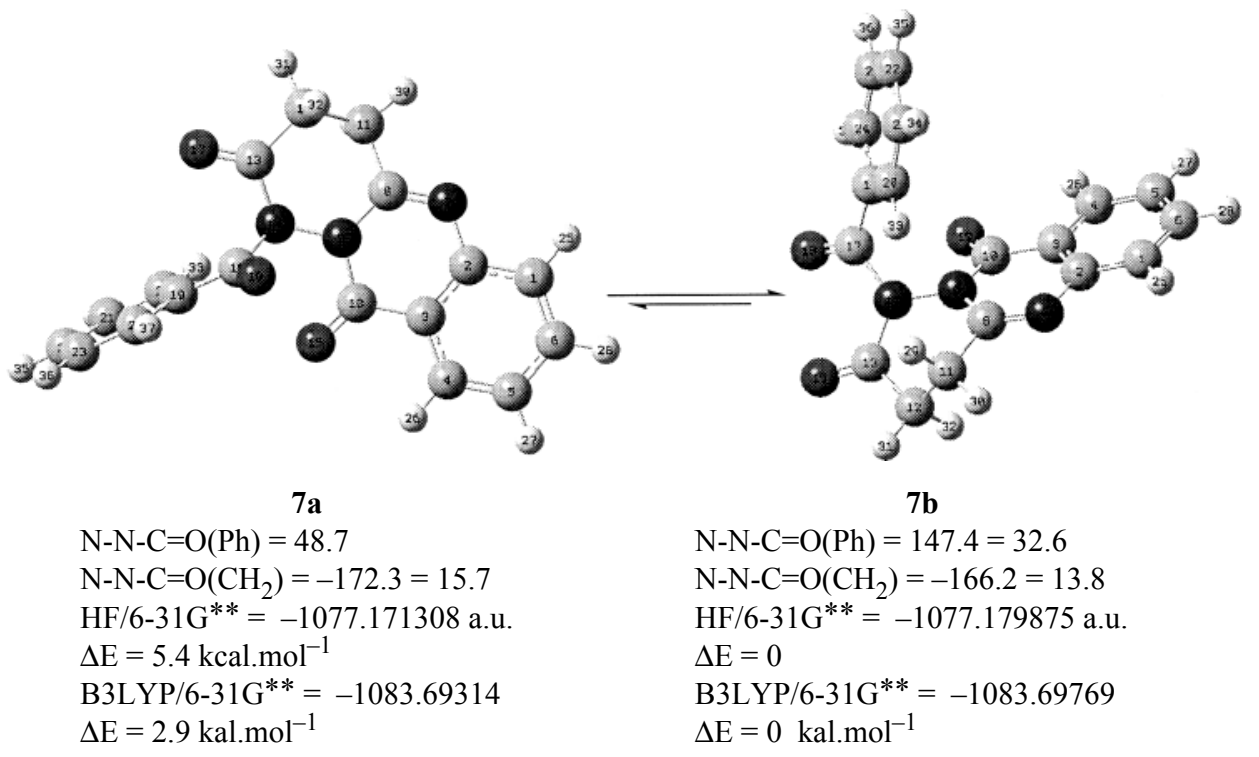

Fig. 1. Optimized geometries structure of pyridazinonequnazolinone (7a) and (7b) rotamers obtained at the ab initio $\left(\mathrm{HF} / 6-31 \mathrm{G}^{* *}\right)$ levels and $\mathrm{B} 3 \mathrm{LYP} / 6-31 \mathrm{G}^{* *}$; dihedral angles $\left({ }^{\circ}\right)$ and relative energies $(\mathrm{kcal} / \mathrm{mol})$ shown.

Energy profile for rotation about dihedral angle $\mathrm{N}-\mathrm{N}-\mathrm{C}=\mathrm{O}(\mathrm{Ph})$ for the 7 a rotamer was studied. The calculations were performed at the semiempirical level (AM1) first and the minima points of the resulting energetic profile were further optimized at the level of $a b$ initio $(\mathrm{HF} / 6-31 \mathrm{G})$. The changes in the total energy with the dihedral angle between $\mathrm{N}-\mathrm{N}-\mathrm{C}=\mathrm{O}$ of the endo and exo rotamers were calculated by a stepwise variation of the dihedral angle. The calculation gave two ground state conformations corresponding to the rotamers $7 \mathrm{a}$ with the $\mathrm{C}=\mathrm{O}$ group of the $\mathrm{N}-\mathrm{N}-\mathrm{C}=\mathrm{O}(\mathrm{Ph})$ dihedral angle exo-oriented and $7 \mathrm{~b}$ the $\mathrm{C}=\mathrm{O}$ endooriented. These two conformations for the endo and exo rotamers are illustrated 
in Fig. 2. As shown the endo rotamer $7 \mathrm{~b}$ is the most stable conformer in this profile $\left(\mathrm{N}-\mathrm{N}-\mathrm{C}=\mathrm{O}=147.4^{\circ}\right.$ ) and the two ground state conformations for endoand exo can be converted into each other. The optimized structural information is shown in Scheme 9.

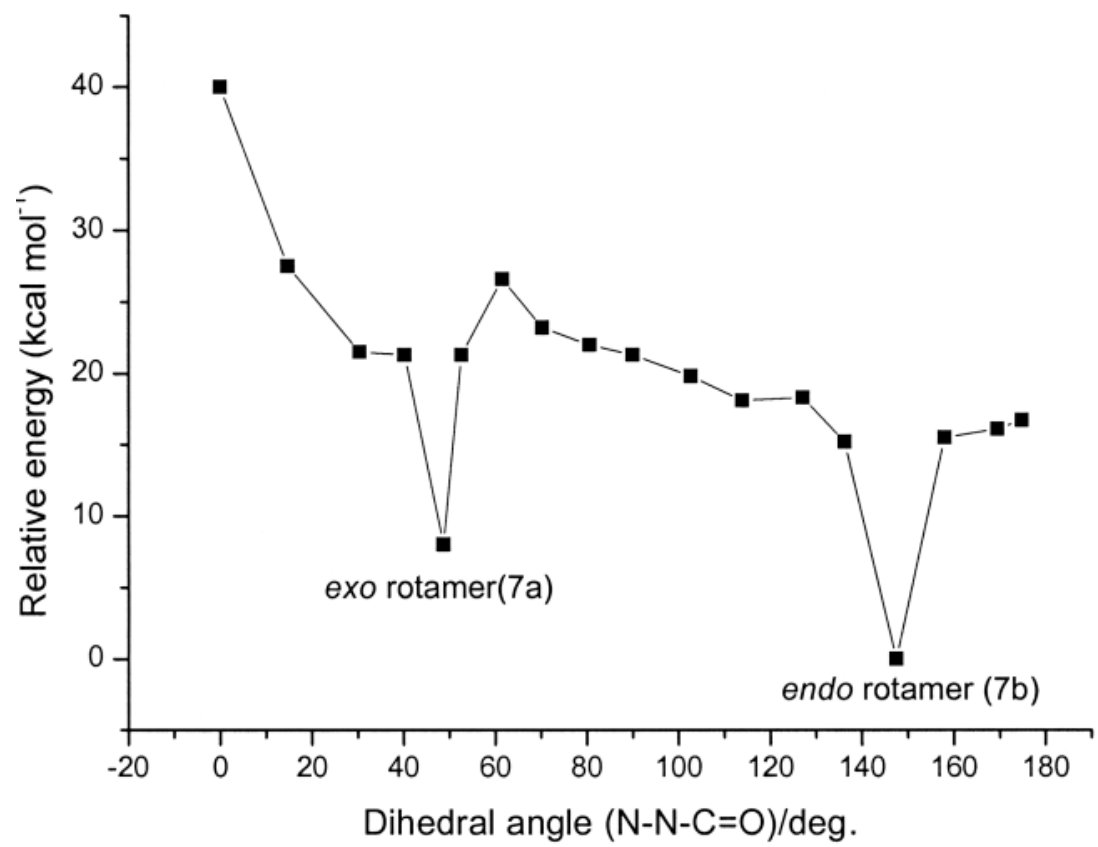

Fig. 2. Energy profile for the rotation about dihedral angle $(\mathrm{N}-\mathrm{N}-\mathrm{C}=\mathrm{O}(\mathrm{Ph})$ of 7 , obtained at the semiempirical (AM1) level. The minima points in each case were optimized at the ab initio (HF/6-31G) level and the corresponding two stable rotamers for exo 7 a and endo $7 \mathrm{~b}$.
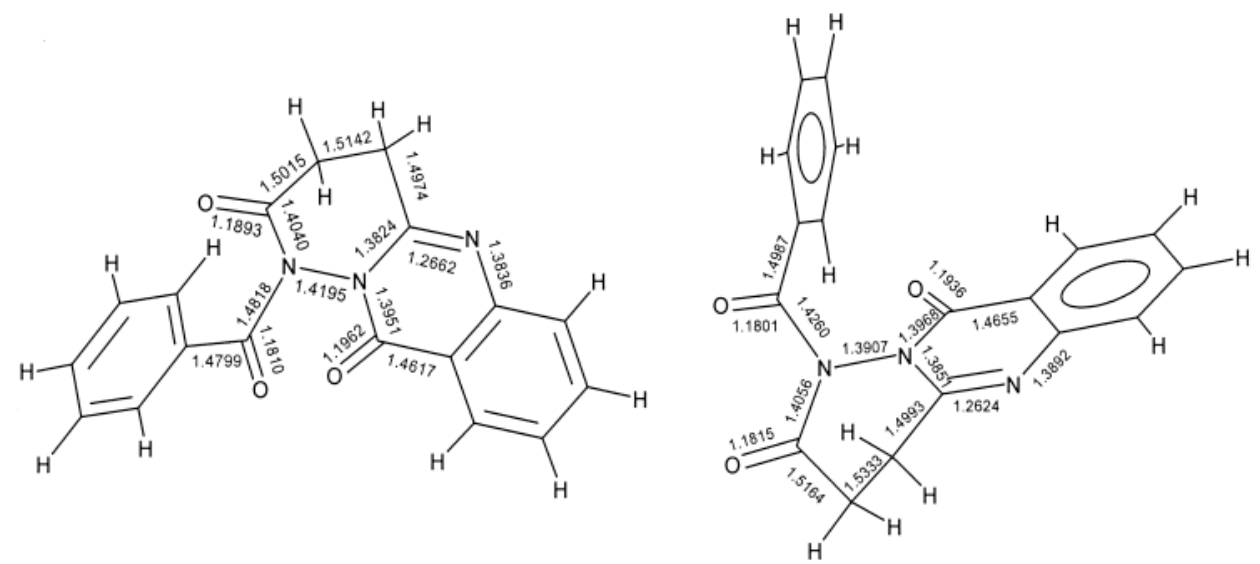

Scheme 9 
In summary, it can be speculated that at room temperature the barrier to $N-N$ bond rotation and concurrent ring-inversion is so low that interconversion between the comparable amounts of the two $N-N$ bond rotamers (diastereoisomers) present results in a time-averaged NMR spectrum. The broadeningsharpening observed in the signals as the temperature was lowered to $-40^{\circ} \mathrm{C}$ suggests the existence of a barrier between two species, conceivably two diastereoisomers as in (Scheme 8).

\section{Experimental}

\section{General}

${ }^{1} \mathrm{H}$ NMR spectra were recorded with Bruker ARX 250 and DRX 300 NMR spectrometers respectively. ${ }^{13} \mathrm{C}$ NMR spectra were recorded at room temperature at $75 \mathrm{MHz}$. NMR spectra were recorded at room temperature in deuterated chloroform. J values are given in $\mathrm{Hz}$ using a Bruker DRX 400 spectrometer. IR spectra of crystalline compounds were recorded at room temperature in dichloromethane and of liquids as thin films using a Perkin-Elmer 298 spectrometer. Standard mass spectra were recorded on a Kratos Concept 1H Magnetic Sector Mass Spectrometer with fast atomic bombardment (FAB). Elemental analysis was carried out by $\mathrm{CHN}$ analysis. Melting point were determined on a Kofler hot stage and are uncorrected. Dichloromethane was distilled from calcium hydride. Routine drying of organic solutions was carried out using magnesium sulfate. All reaction products were dried under vacuum $(\sim \mathrm{mmHg})$ prior to spectroscopic analysis and further use. Removal of solvent under reduced pressure was accomplished by using a rotary evaporator (Buchi) at $(\sim 15 \mathrm{mmHg})$ water pump.

\section{Preparation of Methyl-N-(3-Carboxypropanoyl) Anthranilate (3)}

To solution of Succinic anhydride $(12 \mathrm{~g}, 0.12 \mathrm{~mol})$ was dissolved in sodium dried ether $\left(300 \mathrm{~cm}^{3}\right)$ was added methyl anthranilate $(34 \mathrm{ml}, 0.26 \mathrm{~mol}, 2.2$ equiv.) dropwise and allowed to stir overnight and the solvent removed by evaporation under reduced pressure to give cloudy oil which solidified overnight. Crystallisation of the product gave anthranilate $3(24.51 \mathrm{~g}, 81 \%)$ as colourless crystals, m.p. $131-133^{\circ} \mathrm{C}$ (from ethanol) (Found: $\mathrm{MH}^{+}, 252.0872$. $\mathrm{C}_{12} \mathrm{H}_{14} \mathrm{NO}_{5}$ requires $\left.\mathrm{MH}, 252.0872\right) ; \delta_{\mathrm{H}} 2.79\left(4 \mathrm{H}, \mathrm{s}, \mathrm{CH}_{2} \mathrm{CH}_{2}\right), 3.90(3 \mathrm{H}, \mathrm{s}$, $\left.\mathrm{OCH}_{3}\right), 7.07(1 \mathrm{H}$, ddd, $J 1.6,7.1$ and 8.3, $\mathrm{Ar} 5-\mathrm{H}), 7.52(1 \mathrm{H}$, ddd, $J 1.6,7.1$ and 8.7, Ar 4-H), $8.0(1 \mathrm{H}, \mathrm{dd}, J 1.6$ and 8.3, Ar 6-H) $8.68(1 \mathrm{H}, \mathrm{dd}, J 1.6$ and $8.7 \mathrm{Ar}$ $3-\mathrm{H}), 9.45$ and $11.04\left(2 \mathrm{H}\right.$, br s and $\mathrm{s}, \mathrm{NH}$ or $\left.\mathrm{CO}_{2} \mathrm{H}\right) ; \delta_{\mathrm{C}} 29.5$ and 32.8 $\left(\mathrm{CH}_{2} \mathrm{CH}_{2}\right), 52.7\left(\mathrm{CO}_{2} \mathrm{CH}_{3}\right), 115.5\left[\mathrm{CCO}_{2} \mathrm{CH}_{3}(\mathrm{Ar})\right], 120.9,123.1,131.1$ and 135.0 [4 $\times \mathrm{CH}(\mathrm{Ar})], 141.5[\mathrm{CNHCO}(\mathrm{Ar})], 169.2$ and $170.9(\mathrm{C}=\mathrm{O}) ; v_{\max } / \mathrm{cm}^{-1}$ $3200 \mathrm{vbr}, 1720 \mathrm{brs}, 1590 \mathrm{~s}$ and $1580 \mathrm{~s}$. 


\section{3-Amino-2(2-Carboxyethyl)Quinazolin-4(3H)-One (4)}

Anthranilate $3(22 \mathrm{~g})$ was dissolved in ethanol $\left(30 \mathrm{~cm}^{3}\right)$ and heat with hydrazine $\left(24 \mathrm{~cm}^{3}, 5.5\right.$ equiv.) in a closed steel container at $135^{\circ} \mathrm{C}$ for $12 \mathrm{~h}$. The solution was cooled to room temperature and then in an ice-water bath for $0.5 \mathrm{~h}$, yielding the hydrazine salt in quantitative yield. Dissolving of the salt in water and neutralization using glacial acetic acid gave the 3-aminoquinazolinone 4 $(15 \mathrm{~g}, 73 \%)$ as colourless crystals $\mathrm{mp} 135-137^{\circ} \mathrm{C}$ (from ethanol) (Found: $\mathrm{MH}^{+}$, 234.0878. $\mathrm{C}_{11} \mathrm{H}_{11} \mathrm{~N}_{3} \mathrm{O}_{3}$ requires $\left.\mathrm{MH} 234.0879\right) ; \delta_{\mathrm{H}}\left({ }^{2} \mathrm{H}_{6}\right.$-DMSO), $2.87(2 \mathrm{H}, \mathrm{t}$, $\left.J 7.1 \mathrm{QCH}_{2} \mathrm{CH}_{2}\right), 3.32\left(2 \mathrm{H}, \mathrm{t}, J 7.1, \mathrm{QCH}_{2} \mathrm{CH}_{2}\right), 5.85(2 \mathrm{H}, \mathrm{br}, \mathrm{s}, \mathrm{NH} 2), 7.58$ $(1 \mathrm{H}, \mathrm{dd}, J 1.4,7,1$ and 8. 0, Q6-H), $7.69(1 \mathrm{H}, \mathrm{d}, J 8.0, \mathrm{Q} 8 \mathrm{H}), 7.88(1 \mathrm{H}$, ddd, $J$ $1.4,7.1$ and $8.0, \mathrm{Q} 7-\mathrm{H})$ and $8.21(1 \mathrm{H}, \mathrm{dd}, J 0.9$ and $8.0, \mathrm{Q} 5-\mathrm{H}) ; \delta_{\mathrm{C}}\left({ }^{2} \mathrm{H}_{6}-\right.$ DMSO) $28.8\left(\mathrm{CH}_{2} \mathrm{CH}_{2}\right), 30.2\left(\mathrm{CH}_{2} \mathrm{CH}_{2}\right) 120.0[\mathrm{CC}=\mathrm{O}(\mathrm{Q}), 126.2,126.4$, and $134.3[4 \times C \mathrm{H}(\mathrm{Q})], 146.6[C \mathrm{~N}=\mathrm{C}(\mathrm{Q})) .157 .3[C=\mathrm{N}(\mathrm{Q})], 160.7[\mathrm{C}=\mathrm{O}(\mathrm{Q})]$ and $174.3\left(\mathrm{CO}_{2} \mathrm{H}\right) ; v_{\max } / \mathrm{cm}^{-1} 3320 \mathrm{~m}, 3295 \mathrm{w}, 3200 \mathrm{~m}, 1700 \mathrm{~s}, 1680 \mathrm{~s}, 1640 \mathrm{~s}$ and $1605 \mathrm{~s} ; \mathrm{m} / \mathrm{z} 232\left(\mathrm{M}^{-1}, 100 \%\right), 214$ (29), $188(59)$ and 172 (78).

\section{3-Amino-2-(2-Ethoxycarbonylethyl)Quinazolin-4(3H)-One (5)}

3-Aminoquinazolinone $4(10 \mathrm{~g})$ was added to an excess of methanol $(150 \mathrm{ml})$ containing sulphuric acid $(2 \mathrm{ml})$ and heated at reflux for $3 \mathrm{~h}$. Neutralization of the solution using saturated sodium hydrogen carbonate afforded the 3-aminoquinazolinone methyl ester $5(9.2 \mathrm{~g}, 86 \%)$ as colourless crystals, $\mathrm{mp} 179-181^{\circ} \mathrm{C}$ (from ethanol) (Found: $\mathrm{MH}^{+}$248.1036. $\mathrm{C}_{12} \mathrm{H}_{13} \mathrm{~N}_{3} \mathrm{O}_{3}$ requires $\mathrm{MH}$ 248.1035); $\delta_{\mathrm{H}} 2.93\left(2 \mathrm{H}, \mathrm{t}, J 6.9, \mathrm{QCH}_{2} \mathrm{CH}_{2}\right), 3.36\left(2 \mathrm{H}, \mathrm{t}, J 6.9, \mathrm{QCH}_{2} \mathrm{CH}_{2}\right), 3.71(3 \mathrm{H}, \mathrm{s}$, $\left.\mathrm{CO}_{2} \mathrm{CH}_{3}\right), 4.96\left(2 \mathrm{H}\right.$, br s, $\left.\mathrm{NH}_{2}\right), 7,44(1 \mathrm{H}, \mathrm{ddd}, J 1.2,6.9$ and $8.0, \mathrm{Q} 6-\mathrm{H}), 7.62$ $(1 \mathrm{H}, \mathrm{d}, J 8.3, \mathrm{Q} 8-\mathrm{H}), 7.72(1 \mathrm{H}, \mathrm{ddd}, J 1.4,6.9$ and $8.3, \mathrm{Q} 7-\mathrm{H})$ and $8.23(1 \mathrm{H}, \mathrm{dd}$, $J 1.4$ and 8.0, Q5-H); $\delta_{\mathrm{C}} 34.0\left(\mathrm{QCH}_{2} \mathrm{CH}_{2}\right), 35.1\left(\mathrm{QCH}_{2} \mathrm{CH}_{2}\right) .57 .0\left(\mathrm{CO}_{2} \mathrm{CH}_{3}\right)$, $125.3[C \mathrm{C}=\mathrm{O}(\mathrm{Q})], 131.5,131.8,132.5$ and $139.6[4 \times \mathrm{CH}(\mathrm{Q})] 151.9[\mathrm{CN}=\mathrm{C}$ (Q)], $162.3[\mathrm{C}=\mathrm{N}(\mathrm{Q})], 165,9[\mathrm{C}=\mathrm{O}(\mathrm{Q})]$ and $178,5\left(\mathrm{CO}_{2} \mathrm{CH}_{3}\right) ; v_{\max } / \mathrm{cm}^{-1}$ $3310 \mathrm{~m}, 3200 \mathrm{~m}, 1735 \mathrm{~s}, 1685 \mathrm{~s}, 1660 \mathrm{~m}, 1610$ and $1600 \mathrm{~m}$.

\section{3,4-Dihydro-1H-Pyridazino[6,1-b]Quinazline-2,10-Dione (6)}

3-Aminoquinazolinone $5(5 \mathrm{~g})$ was heated at $190^{\circ} \mathrm{C}$ until methanol evolution ceased ( $5 \mathrm{~min}$ ). On cooling to room temperature, the solid mass was digested in ethanol $(20 \mathrm{ml})$ to provide the pyridazinone $6(4 \mathrm{~g}, 87 \%)$ as a light-brown solid, crystallization from glacial acetic acid. (Found: $\mathrm{MH}^{+}, 216.0773 . \mathrm{C}_{11} \mathrm{H}_{9} \mathrm{~N}_{3} \mathrm{O}_{2}$ requires $\mathrm{MH} 216.0773) \delta_{\mathrm{H}} 2.83\left(2 \mathrm{H}, \mathrm{m}, \mathrm{QCH}_{2} \mathrm{CH}_{2}\right), 3.30\left(2 \mathrm{H}, \mathrm{m}, \mathrm{QCH}_{2} \mathrm{CH}_{2}\right)$, $7.54(1 \mathrm{H}$, ddd, $J 1.6,7.1$ and 8.3, Q6-H), $7.72(1 \mathrm{H}, \mathrm{dd}, J 1.6$ and 8.3, Q8-H), $7.81(1 \mathrm{H}$, ddd, $J 71.6,7.1$ and 8.3, Q7-H), $8.30(1 \mathrm{H}$, dd, $J 1.6$ and 8.3, Q5-H) and $9.70(1 \mathrm{H}$, br s, $\mathrm{NH}) ; \delta_{\mathrm{C}} 28.9$ and $29.2\left(\mathrm{CH}_{2} \mathrm{CH}_{2}\right), 121.0[\mathrm{CC}=\mathrm{O}(\mathrm{Q})], 126.9$, 
127.8 and 134.5 [3 $\times \mathrm{CH}(\mathrm{Q})$ one peak overlaid], $146.9(\mathrm{CN}=\mathrm{C}(\mathrm{Q})], 149.2[\mathrm{CN}$ (Q), $155.5[\mathrm{C}=\mathrm{O}(\mathrm{Q})]$ and $168.8(\mathrm{CONH}) ; v_{\max } / \mathrm{cm}^{-1} 1670 \mathrm{brs}$ and $1600 \mathrm{~s}$.

\section{N-Benzoylation of Pyridasinon/6,1-b]Quinazoline 7}

Pyridazinone 6 (0.1 g, $0.47 \mathrm{mmol})$ was dissolved in dry dichloromethane (2) $\left.\mathrm{cm}^{3}\right)$ containing dry pyridine $(0.07 \mathrm{~g}, 0.94 \mathrm{mmol})$. Benzoyl chloride $(0.131 \mathrm{~g}$, $0.94 \mathrm{mmol}$ ) was added dropwise over $10 \mathrm{~min}$ with subsequent stirring at room temperature for $24 \mathrm{~h}$. A further quantity of dichloromethane $(10 \mathrm{ml})$ was added and the solution washed consecutively with sodium hydrogen carbonate, water and brine solution before being dried over magnesium sulphate. Removal of the solvent under reduced pressure afforded a black oil. Purification by flash chromatography eluting with light petroleum-ethyl acetate (4:1) provided the $\mathrm{N}$ benzoylpyridazinone 7 as colourless crystals $(0.11 \mathrm{~g}, 72 \%)$ (Found: $\mathrm{M}^{+}$, 319.0957). $\mathrm{C}_{18} \mathrm{H}_{13} \mathrm{~N}_{3} \mathrm{O}_{3}$ requires $\left.\mathrm{M} 319.0957\right) ; \delta_{\mathrm{H}} 2.91\left(2 \mathrm{H}, \mathrm{m}, \mathrm{CH}_{2} \mathrm{C}=\mathrm{N}\right), 3.27$ $\left(2 \mathrm{H}, \mathrm{m}, \mathrm{CH}_{2} \mathrm{CO}\right), 7.40-7.54[4 \mathrm{H}, \mathrm{m}, 3 \times \mathrm{CH}(\mathrm{Ph})$ and $6-\mathrm{H}(\mathrm{Q})], 7.57-8.0[4 \mathrm{H}, \mathrm{m}$, $2 \times \mathrm{CH}(\mathrm{pH}), 7-$ and $8-\mathrm{H}(\mathrm{Q})]$, and $8.22[1 \mathrm{H}, \mathrm{d}, J 8.2,5-\mathrm{H}(\mathrm{Q})] ; \delta_{\mathrm{C}}(100 \mathrm{MHz})$ 28.7 and $32.9\left(\mathrm{CH}_{2} \mathrm{CH}_{2}\right), 121.6[\mathrm{CC}=\mathrm{O}(\mathrm{Q})], 122.4,127.6,127,7,127.9,128.7$, $128.9,132.2,134.2$ and $135[5 \times C \mathrm{H}(\mathrm{Ph})$ and $4 \times C \mathrm{H}(\mathrm{Q})] 146.3[\mathrm{CN}=\mathrm{C}(\mathrm{Q})]$, $157.3[\mathrm{C}=\mathrm{N}(\mathrm{Q})], 159.5[\mathrm{C}=\mathrm{O}(\mathrm{Q})$, and 170.9 and $179.0(2 \times \mathrm{CO})$.

\section{Methyl-N-(3-Carboxy-2-Methylpropanoyl)Anthranilate (12) and Methyl-N- (3-Carboxy-3-Methylpropanoyl)Anthranilate (13)}

To racemic methyl succinic anhydride $(6 \mathrm{~g})$ dissolved in sodium dried ether $\left(200 \mathrm{~cm}^{3}\right)$ was added methyl anthranilate $(9.5 \mathrm{~g}, 1.2$ equiv.) dropwise and allowed to stir at room and allowed to stir at room temperature for $48 \mathrm{~h}$ and the solvent removed by evaporation under reduced to give cloudy oil which solidified over $12 \mathrm{~h}$. A proton NMR spectrum of the crude product showed the presence of 8:1 mixture of regioisomers by comparison of the signals at $\delta_{\mathrm{H}}$ and 1.31 and 1.37, respectively. Crystallization of the crude product $(5.2 \mathrm{~g})$ from ethanol provided the major regioisomer 2-methyl anthranil ester $12(4.00 \mathrm{~g}, 33 \%)$ as a colourless solid $\mathrm{mp} 70-71^{\circ} \mathrm{C}$ (from ethanol) (Found: $\mathrm{C}, 58.76 ; \mathrm{H}, 5.71 ; \mathrm{N}, 5.27$. $\mathrm{C}_{13} \mathrm{H}_{15} \mathrm{NO}_{5}$ requires $\left.\mathrm{C}, 58.86 ; \mathrm{H} .5 .70 ; \mathrm{N}, 5.28 \%\right) ; \delta_{\mathrm{H}} 1.31(3 \mathrm{H}, \mathrm{d}, J 7.1, \mathrm{CH}$ $\left(\mathrm{CH}_{3}\right), 2.55[1 \mathrm{H}, \mathrm{dd}, J 76.0$ and 15.6, $\mathrm{CHHCH}), 2.90[1 \mathrm{H}, \mathrm{dd}, J 7.8$ and 15.6, $\mathrm{CH} H(\mathrm{CH})) 3.10[1 \mathrm{H}$, app. septet, $J 6.9$ and $7.6 \mathrm{CH}(\mathrm{CH})] 3.91(3 \mathrm{H}$, s, $\left.\mathrm{CO}_{2} \mathrm{CH}_{3}\right), 7.07(1 \mathrm{H}$, dd, $J 1.2,7.1$ and 8.0, $\mathrm{Ar} 5-\mathrm{H}), 7.51(1 \mathrm{H}$, ddd, $J 71.6,7.1$ and 8.5, Ar 4-H), $8.00(1 \mathrm{H}, \mathrm{dd}, J 1.6$ and 8.0, Ar 6-H), $8.66(1 \mathrm{H}, \mathrm{d}, J 78.5, \mathrm{Ar}$ $3-\mathrm{H}), 9.10$ and $11.14\left(2 \mathrm{H}\right.$, br s and s, $\mathrm{NH}$ or $\left.\mathrm{CO}_{2} H\right) ; \delta_{\mathrm{C}} 17.3\left[\mathrm{CH}\left(\mathrm{CH}_{3}\right)\right] .36 .2$ $\left[\mathrm{CH}_{2} \mathrm{CH}\left(\mathrm{CH}_{3}\right)\right], 41.5\left[\mathrm{CH}_{2} \mathrm{CH}\left(\mathrm{CH}_{3}\right)\right], 52.8\left(\mathrm{CO}_{2} \mathrm{CH}_{3}\right), 115.4\left[\mathrm{CCO}_{2} \mathrm{CH}_{3}(\mathrm{Ar})\right]$, $120.9,123.0,131.2$ and 135.0 [4 $\times \mathrm{CH}(\mathrm{Ar})], 141.6$ [C NHCO (Ar)], 169.1 and 
$170.5\left[\mathrm{CO}_{2} \mathrm{CH}_{3}(\mathrm{Ar})\right.$ and $\left.\mathrm{NHCO}(\mathrm{Ar})\right]$ and $181.3\left(\mathrm{CO}_{2} \mathrm{H}\right) ; v_{\max } / \mathrm{cm}^{-1} 3260 \mathrm{w}$, $1690 \mathrm{~s}, 1700 \mathrm{~s}, 1600 \mathrm{~s}$ and $1590 \mathrm{~s}$.

\section{3-Amino-2-(2-Carboxypropyl)Quinazolin-4(3H)-One $\mathrm{QNH}_{2}$ (14)}

To anthranilate $12(2 \mathrm{~g})$ was dissolved in ethanol $\left(10 \mathrm{~cm}^{3}\right)$ were added hydrazine monohydrate ( $2 \mathrm{~g}, 5.4$ equiv.) but the reaction mixture heated under reflux for $5 \mathrm{~h}$. Subsequent stirring at room temperature overnight, the bulk of the solvent was removed under reduced pressure and the residue digested in water. Neutralisation using glacial acetic acid gave the 3-aminoquinazolinone 14 (1.23 g, $65 \%$ ) as colourless crystals, m.p. $145-146^{\circ} \mathrm{C}$ (from ethanol) (Found: C, 58.24; $\mathrm{H}, 5.33 ; 16.98 . \mathrm{C}_{12} \mathrm{H}_{13} \mathrm{~N}_{3} \mathrm{O}_{3}$ requires $\left.\mathrm{C}, 58.29 ; \mathrm{H}, 5.30 ; \mathrm{N}, 16.99 \%\right) ; \delta_{\mathrm{H}}\left({ }^{2} \mathrm{H}_{6}\right]$ DMSO) $1.42\left[3 \mathrm{H}, \mathrm{d}, J 7.1, \mathrm{CH}\left(\mathrm{CH}_{3}\right)\right], 3.16(1 \mathrm{H}, \mathrm{dd}, J 6.0$ and $16.3, \mathrm{CH}(\mathrm{CH})]$, 3.33 [app. sextet, $J 7.1, \mathrm{CH}(\mathrm{CH})_{3}$ ] $, 3.57[1 \mathrm{H}, \mathrm{dd}, J 7.8 \mathrm{~d}, 16.3, \mathrm{CH} H(\mathrm{CH})], 5.94$ $\left(2 \mathrm{H}\right.$, br s, $\left.\mathrm{NH}_{2}\right), 7.64(1 \mathrm{H}, \mathrm{ddd}, J 0.9,7.1$-and $8.0, \mathrm{Q} 6-\mathrm{H}), 7.76(1 \mathrm{H}, \mathrm{d}, J 8.5, \mathrm{Q}$ $8-\mathrm{H}), 7.94(1 \mathrm{H}, \mathrm{ddd}, J 1.6,7.1$ and 8.5 , Q $7-\mathrm{H})$ and $8.29(1 \mathrm{H}, \mathrm{dd}, J 1.6$ and 8.0 Q 5-H); $\left.\delta_{\mathrm{C}}\left({ }^{2} \mathrm{H}_{6}\right),-\mathrm{DMSO}\right) 17.6\left[\mathrm{CH}\left(\mathrm{CH}_{3}\right)\right], 36.2\left[\mathrm{CH}\left(\mathrm{CH}_{3}\right)\right], 37.0\left[\mathrm{CH}_{2} \mathrm{CH}\right.$ $(\mathrm{CH} 3)], 120.1[\mathrm{CC}=\mathrm{O}(\mathrm{Q})], 126.2,126.4,127.2$ and $134.2(4 \times \mathrm{CH}(\mathrm{Q})], 146.6$ $(C \mathrm{~N}=\mathrm{C}(\mathrm{Q})], 156.7[C=\mathrm{N}(\mathrm{Q})], 160.7[C=\mathrm{O}(\mathrm{Q})]$ and $177.3\left(\mathrm{CO}_{2} \mathrm{H}\right) ; v_{\max } /$ $\mathrm{cm}^{-1}, 3345 \mathrm{w}, 1700 \mathrm{~m}, 1680 \mathrm{~m}$ and $1605 \mathrm{~m}$.

\section{3-Methyl-4-Dihydro-l-Acetylpyridazino[6,1-b]Quinazoline-2,10-Dione (15)}

3-Aminoquinazolinone $14(0.1 \mathrm{~g}, 0.4 \mathrm{mmol})$ was allowed to stir in acetic anhydride $(3 \mathrm{ml})$ at $100^{\circ} \mathrm{C}$ for $2 \mathrm{~h}$. The excess acetic anhydride was removed under reduced pressure resulting viscous yellow oil $(89 \mathrm{mg})$. Purification by flash chromatography eluting with neat ethyl acetate gave a sample $(52 \mathrm{mg})$ which possessed two spots on TLC $\left(\mathrm{R}_{\mathrm{f}} 0.44\right.$ and 0.22$)$. Repeat elution using light petroleum-ethyl acetate (1:3) afforded the product pyridazinone 15 as a viscous colourless oil $\mathrm{R}_{\mathrm{f}} 0.44$ (27 mg, 24.5\%) (Found: $\mathrm{MH}^{+}, 272.1035 . \mathrm{C}_{14} \mathrm{H}_{14} \mathrm{~N}_{3} \mathrm{O}_{3}$ requires MH. 272.1035); $\delta_{\mathrm{H}} 1.37\left(3 \mathrm{H}, \mathrm{d}, J 6.2, \mathrm{CHCH}_{3}\right), 2.72\left(3 \mathrm{H}, \mathrm{s} . \mathrm{NCOCH}_{3}\right)$, $2.94\left[2 \mathrm{H}, \mathrm{m}, \mathrm{CH}_{2} \mathrm{CH}\left(\mathrm{CH}_{3}\right)\right], 3.12\left[1 \mathrm{H}, \mathrm{m} . \mathrm{CH}_{2} \mathrm{CH}\left(\mathrm{CH}_{3}\right)\right] .7 .51(1 \mathrm{H}, \mathrm{ddd}, J 1.2$, 7.1 and 8.0, Q 6-H), $7.66(1 \mathrm{H}, \mathrm{d}, J 8.0$, Q $8-\mathrm{H}), 7.79(1 \mathrm{H}$, ddd, $J 1.6,7.1$ and 8.0, Q 7-H) and $8.26\left(1 \mathrm{H}, \mathrm{dd}, J 1.6\right.$ and 8.0, Q 5-H); $\delta_{\mathrm{C}}(100 \mathrm{MHz}) 14.6$ $\left(\mathrm{CHCH}_{3}\right), 26.2\left[\mathrm{CH}_{2} \mathrm{CH}\left(\mathrm{CH}_{3}\right)\right] 36.3\left[\mathrm{CH}_{2} \mathrm{CH}\left(\mathrm{CH}_{3}\right)\right], 37.5\left(\mathrm{NCOCH}_{3}\right), 121.7$ $[C \mathrm{C}=\mathrm{O}(\mathrm{Q})], 127.5,127.8,127.9$ and $135.4[4 \times \mathrm{CH}(\mathrm{Q})], 146.2[\mathrm{CN}=\mathrm{C}(\mathrm{Q})]$, $151.7[C=\mathrm{N}(\mathrm{Q})], 156.8[C=\mathrm{O}(\mathrm{Q})], 166.6\left[\mathrm{CH}\left(\mathrm{CH}_{3}\right) C=\mathrm{O}\right]$ and $172.9[\mathrm{~N}$ $\left.\left(\mathrm{O}=\mathrm{CCH}_{3}\right)\right] ; v_{\max } / \mathrm{cm}^{-1} 1745 \mathrm{~m}, 1700 \mathrm{~m}, 1630 \mathrm{w}$ and $1610 \mathrm{w}$. 


\section{References}

[1] Chao, Q., Deng, L., Shih, H., Leoni, L., Genini, D., Cason, D.A. and Cattam, H.B., J. Med. Chem., 42: 3860 (1999).

[2] Mannschreck, A., Koller, H., Stuhler, G. and Davies, M.A., Eur. J. Med. Chem., 19: 381 (1984).

[3] Hess, H.J., Cromin, T.H. and Scriabine, A., J. Med. Chem., 11: 130 (1968).

[4] Xia, Y., Yang, Z., Hour, M., Kuo, S., Xia, P., Bastow, K.F., Nakanishi, Y., Nampoothiri, P., Hackt, T., Hamel, E. and Lee, K., Med. Chem. Lett., 11: 1193 (2001).

[5] Bandurco, V., Wong, E.M., Levine, S.D. and Hajos, Z.G., J. Med. Chem., 24: 1456 (1981).

[6] Al-Sehemi, A.G., Atkinson, R.S., Fawcett, J. and Russell, D.R., Chem. Commun., 43 (2000).

[7] Al-Sehemi, A.G., Atkinson, R.S., Fawcett, J. and Russell, D.R., Tetrahedron lett., 41: 2239 (2000).

[8] Al-Sehemi, A.G., Atkinson, R.S., Fawcett, J. and Russell, D.R., Tetrahedron lett., 41: $2243(2000)$.

[9] Al-Sehemi, A.G., Atkinson, R.S., Fawcett, J. and Russell, D.R., J. Chem. Soc., Perkin Trans., 1: 4413 (2000).

[10] Al-Sehemi, A.G., Atkinson, R.S. and Fawcett, J., J. Chem. Soc., Perkin Trans., 1: 257 (2002).

[11] Al-Sehemi, A.G., Atkinson, R.S. and Meades, C.K., Chem. Commun., 2684 (2001).

[12] Al-Sehemi, A.G., J. Saudi Chem. Soc., 8: 461 (2004).

[13] Frisch, M.J., Trucks, G.W., Schlegel, H.B., Scuseria, G.E., Robb, M.A., Cheeseman, J.R., Zakrzewski, V.G., Montgomery, J.A., Jr., Stratmann, R.E., Burant, J.C., Dapprich, S., Millam, J.M., Daniels, A.D., Kudin, R.N., Strain, M.C., Farkas, O., Tomasi, J., Barone, V., Cossi, M., Cammi, R., Mennucci, B., Pomelli, C., Adamo, C., Clifford, S., Ochterski, J., Petersson, C.A., Ayala, P.Y., Cui, Q., Morokuma, K., Malick, D.K., Rabuck, A.D., Raghavachari, K., Foresman, J.B., Cioslowski, J., Ortiz, J.V., Baboul, A.G., Stefanov, B.B., Liu, G., Liashenko, A., Piskorz, P., Komaromi, I., Gomperts, R., Martin, R.L., Fox, D.J., Keith, T., Al-Laham, M.A., Peng, C.Y., Nanayakkara, A., Gonzalez, C., Challacombe, M., Gill, P.M.W., Johnson, B., Chen, W., Wong, M.W., Andres, J.L., Gonzalez, C., Head-Gordon, M., Replogle, E.S. and Pople, J.A., Gaussian, Inc., Pittsburgh PA (1998).

[14] Binkley, J.S., Pople, J.A. and Hehre, W.J., J. Am. Chem. Soc., 102: 939 (1980). 


\section{تحضير وتوصيف ودراسة فراغية لمركبات بيريدازين كينازولينون}

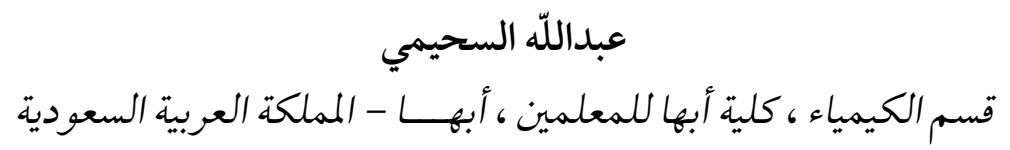

المستخلص. تم تحضير مركبات pyridazino[6,1-b]quinazolinones في

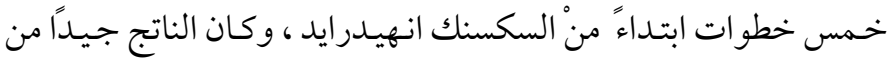

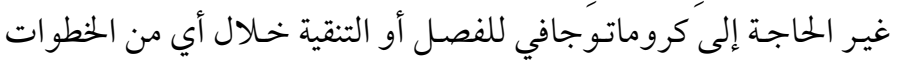

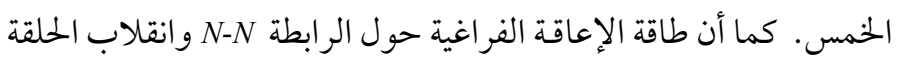
في المركبين V و V كانت منخفضـة عند درجة حرارة الغرفة مقـارنة ب

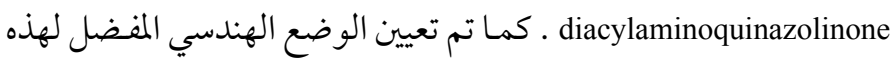
المركبـات باستخخدام حسـابات نظرية بواسطة Hartree-Fock وحسـابات الكثـافــة الوظيـــــــــة النظريــة (Density Function Theory calculation) . [RHF/6-31G**(d), B3LYP/6-311G**(d) 